\title{
A Geospatial Approach to Climatic Zone Specific Effective Horticultural Planning in East Khasi Hills District of Meghalaya, India
}

\author{
Jonali Goswami, Dibyajyoti Chutia, S. Sudhakar \\ Department of Space, North Eastern Space Applications Centre, Umiam, India \\ Email: \{jonali.goswami, d.chutia, s.sudhakar\}@nesac.gov.in
}

Received February 20, 2012; revised March 19, 2012; accepted March 29, 2012

\begin{abstract}
Climatic zone is one of the most important units for horticultural planning. Survival and failure of particular land use or farming system in a given region heavily relies on careful assessment of agroclimatic resources. Large variety of crops is being grown in Meghalaya traditionally, based on the needs and cultural practices of people without any consideration to the suitability of the climate. This study attempts to make adjustments with the climate based upon scientific knowledge to make the best use of the natural resources so as to recommend more area under horticultural crops. This has been made by identifying existing land use and appropriate land use strategies mainly for horticultural crops for each agro-climatic region. Modern Geospatial technology such as satellite Remote Sensing (RS) and Geographical Information System (GIS) and GPS have been used effectively to provide newer dimensions in identifying suitable sites for various horticultural crops and also for appropriate monitoring and management of land resources in an integrated manner with reference to agro-climatic condition.
\end{abstract}

Keywords: Climatic Zone; Geospatial Technology; RS; GIS

\section{Introduction}

Meghalaya has a unique geographical position, cultural and socio-economic conditions, but unable to made much progress as compared to the rest of India due to various reasons viz., infrastructure bottlenecks, institutional weakness, technological gaps, etc. In an age of liberalization of the economy and globalization, horticulture in Meghalaya, with their diversity in plant species and climate, can produce variety of commodities that have high export value in the regional and global markets. Since land holdings of this region are small, the farmers should move from subsistence farming to high-valued crops like vegetables, fruit, medicinal and aromatic plants. These crops require more labour and knowledge of cultivation and needs support of modern technologies, cold storage and marketing [1]. However, farmers of the region need timely expert advice to make them more productive and competitive.

The climate and other natural resources of varied degree have undergone changes in different parts of the Meghalaya state [2]. These changes have occurred due to deforestation and over exploitation under various cropping system. There is a great probability of significant effects of increased climatic variability on short season crops such as vegetables, if changes occur during critical periods of growth. Such crops will have limited time to adapt to adverse environments. The production of fruits may be significantly affected if the changes in climate happen to coincide with the critical periods [3]. Now it has become essential to assess the land cover, various climatic parameters and other natural resources which are likely to cause harmful effects on the productivity of the crops due to over exploitation. Large numbers of crops are being grown in Meghalaya traditionally in many areas based on the needs and cultural practices of people without any consideration to the fitness of the climate. With staggering increase in food demands and limits on the availability of land and water, the resource based agriculture needs careful management to increase farm produce from a unit area. One of the approaches to increase the productivity is to identify the climatic constraints and evolve strategies to overcome them.

Many a times the programs undertaken by Government institutions to address specific problems of rural masses get poorly implemented due to insufficient technical inputs, lack of zeal and transparency in implementtation and ineffective monitoring methods [4]. The Information and Communication Technology (ICT), RS, and GIS are technologies that are creating new vistas for connecting people, to obtain and disseminate information 
and to bring about a new revolution in many developmental sectors. With rapid advancements in geospatial technologies have now made it possible to use and analyze diverse map information which are vital to make sound decisions at the local or regional level planning, implementation of various government developmental schemes and action plans, infrastructure development, disaster management support and industry development.

\section{Study Area}

East Khasi Hills is one of the seven districts of the state of Meghalaya, India. The district occupies an area of $2748 \mathrm{Sq} \cdot \mathrm{km}$. and it lies between $25^{\circ} 07^{\prime \prime} \& 25^{\circ} 41^{\prime \prime N}$ Latitude and $91^{\circ} 21^{\prime \prime} \& 92^{\circ} 09^{\prime \prime E}$ Longitude (Figure 1). Shillong is the headquarter of the district. The district consists of seven Community and Rural Development blocks at present.

\section{Agro-Climatic Characteristics}

As per the classification scheme of National Bureau of Soil Survey and Land Use Planning (NBSS\&LUP), the district falls under warm per humid Agro-eco Sub Region. The climate of East Khasi Hills varies according to elevation and exposure. The Central highlands with elevation of 1500 metres and above have a temperate climate; places at lower elevations are warm and humid. Rainfall also varies from place to place. Places on the southern escarpment, facing the south-west monsoons (viz. Pynursla-Cherrapunji-Mawsynram) receive an average annual rainfall of $9000-11,000 \mathrm{~mm}$. The soils of district are light to heavy in texture. They are acidic and rich in organic matter but poor in phosphorous. Potash content varies from medium to high. Red soils are commonly found in the central and sub-montane regions while black and red loam occurs in the low lying hills. The wide variations in the soil-climatic conditions offer scope for the cultivation of a wide variety of agricultural and horticultural crops, ranging from species adapted to tropical to temperate climates. East Khasi Hills district is broadly covered under the agro-climatic region, MeghalayaMikir region with nine climatically homogeneous regions [5]. About 53\% of total area of the district is covered under cold extremely wet (27\%) and cold wet zone (26\%) which lies in altitude more than $1000 \mathrm{~m}$ where mean annual temperature is around $10^{\circ} \mathrm{C}-20^{\circ} \mathrm{C}$ with good amount of rainfall sufficient enough to meet the potential evapotranspiration of the plants (Figure 2, Table 1).

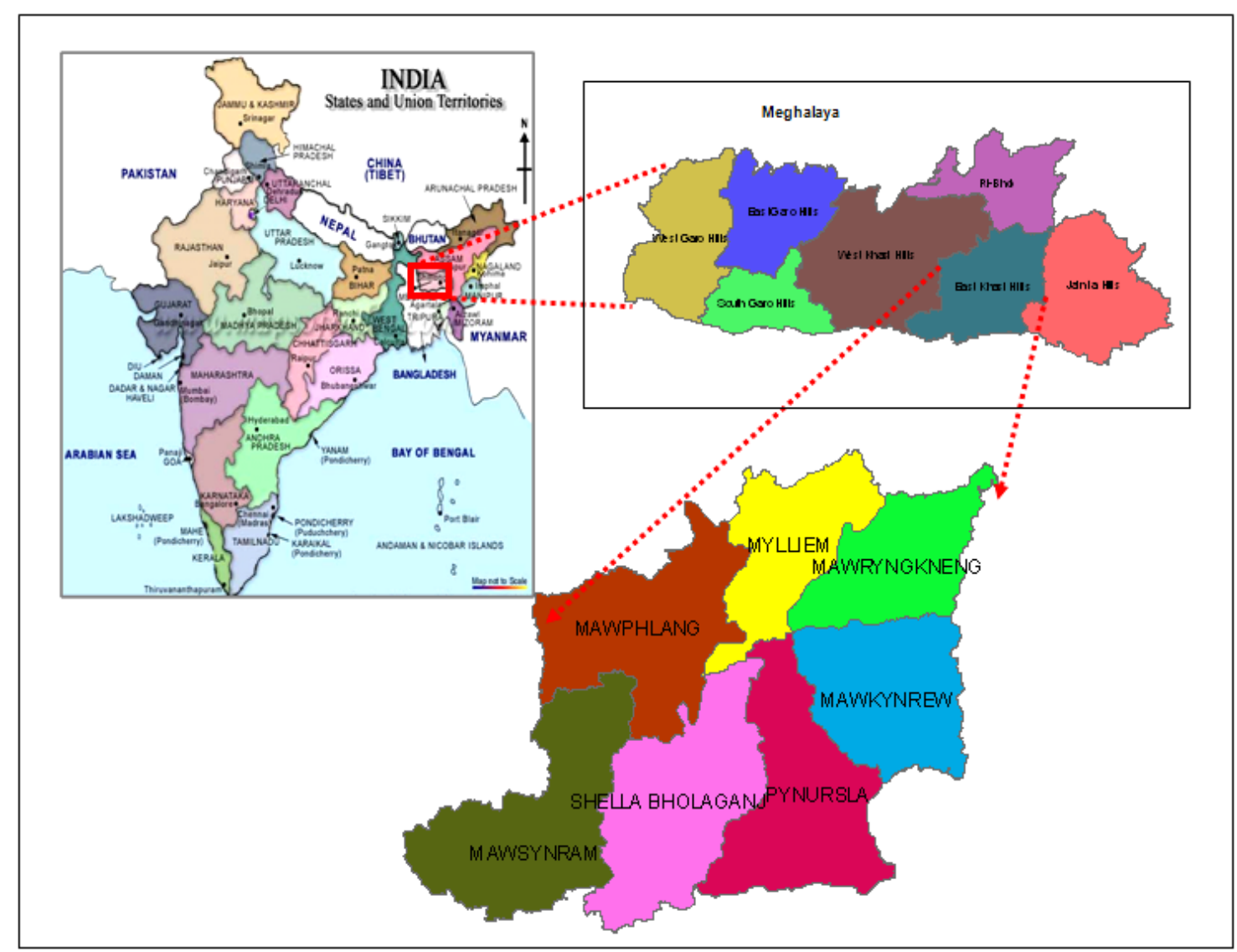

Figure 1. Study area-East Khasi Hills district of Meghalaya. 

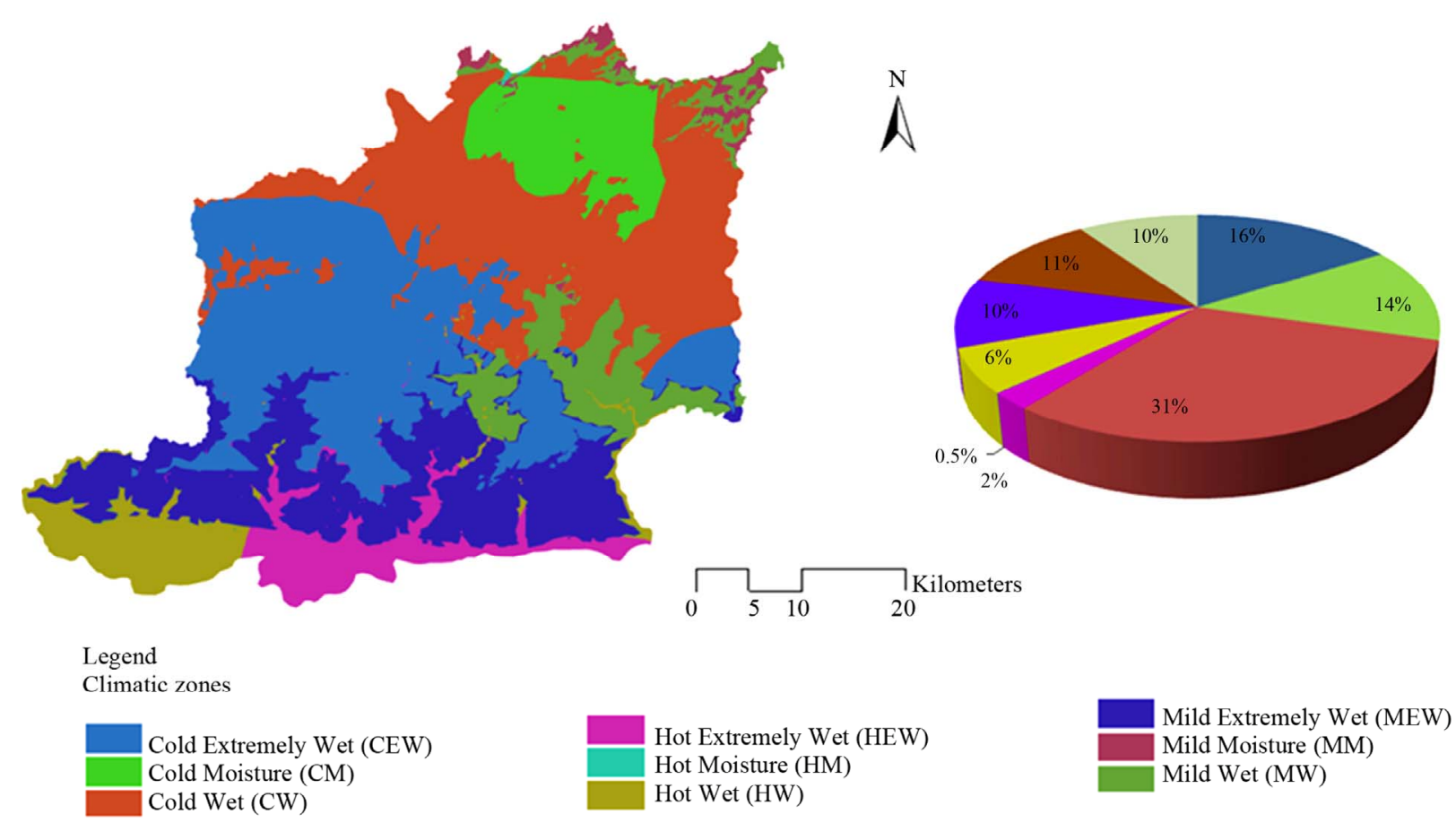

Figure 2. Distribution of climatic zones.

Table 1. Climatic characterization of East Khasi Hills district.

\begin{tabular}{cccccc}
\hline Climatic group & Elevation (mm) & AWC & Soil texture & Present land use & Area (Sq·Km) \\
\hline CEW & $1000-1900$ & Very High (VH), High (H) & Loam, Sand & Plantation crop, Grass land, pine, subtropical forest & 775.54 \\
CW & $1000-1800$ & VH,H & Loam & $\begin{array}{c}\text { Agro-Horticulre, pine, grass land subtropical forest } \\
\text { Agro-horticulture, degraded forest, grassland, }\end{array}$ \\
CM & $1000-1500$ & VH,H & Loam & subtropical forest & 228.72 \\
MEW & $200-1300$ & VH,H & Loam, Sand & Grass land, pine, subtropical forest & L29.78 \\
MW & $200-1300$ & VH,H & Loam, Sand & Grass land, pine, subtropical forest \\
MM & $200-1000$ & VH,H & Loam, Clay & $\begin{array}{c}\text { Agriculture, current and abandoned jhum, } \\
\text { semievergreen and evergreen forest }\end{array}$ \\
HEW & $<200$ & VH,H & Loam, Sand & Agriculture, Sub tropical grassland \\
HW & $<200$ & VH,H & Loam, Sand & Agriculture, Sub tropical grassland \\
HM & $<200$ & VH,H & Loam, Clay & Agriculture, Bamboo, current and abandoned jhum, \\
forest
\end{tabular}

The agro-climatic variation within the districts offers much scope for cultivation of temperate as well as tropical fruits and vegetables. Few important temperate fruits like Plum, peach, pear, apricot etc. are cultivated successfully in the moderately high altitude areas [6]. Fruits crops like oranges, lemon, papaya, jackfruit, pineapple are also grown extensively. Potato is one of the major cash crops which is about 10 percent of the net area sown in the state. Despite the great importance in the state, poor productivity of potato is due to its hilly terrain, rainfed condition high incidence of diseases and pests and poor knowledge about improved practices for potato cultivation [7]. Cabbage and maize occupies the second place, just next to potato. These crops are grown only once in a year. Carrots, tomatoes, garlic, mustard etc. are also cultivated less because of the high cost of seed, fertilizer and low return. Arecanut plantation dominates most of the agricultural land. Betel leaf is grown along with Arecanut plantations. Pepper, tez patta, broom stick, turmeric, ginger, sweet potatoes are cultivated in most of 
the part of the district.

\section{Objectives}

The main objective of this study is to provide inputs for effective planning of horticultural development activities with respect to the climatic variability in the district of East Khasi Hills of Meghalaya using a novel geospatial approach.

\section{Geo-Spatial Approach}

Existing natural resource databases prepared under various national projects of Indian Space Research Organization (ISRO)/Department of Space (DOS) such as current land use, wastelands, soil, slope, ground water prospect and drainage at 1:50 K scale have formed the core of primary input parameters. Land use strategies appropriate for each agro-climatic region were arrived at by integrating information on climatic and soil-physiographic viz. geomorphology, soil, slope, surface water availability, ground water prospects, current land use/cover and crop requirements [8,9]. We have built a spatial model in a spatial analyst environment where various inputs parameters defined in the form of a criteria table has been incorporated into a weighted overlay function (Figure 3). The criteria table follows the specific guidelines of Food and Agriculture Organization (FAO) and National Bureau of Soil Survey \& Land Use Planning (NBSS\&LUP). Incorporation of agro-climatic zones along with information on socio economic, proximity to roads \& settlements has further enhanced the formulating of suitability criteria for the action plan in the model.

Each climatic zone represents the favourable climate for growth of specific horticultural crops. Unfavorable weather and climatic conditions produce a stress on vegetation [10]. Many workers attempted to identify and specify the suitability criteria for different annual crops through land evaluation approach using multivariate regression models with the help of soil, climatic parameters with yield data [11]. These are useful for planning a uniform horticultural development of the state and for designing the most profitable cropping pattern.

\section{Results and Discussion}

The agro-climatic conditions in East Khasi Hills district favour the cultivation of horticultural crops round the year. Suitable areas for cultivation of various horticulture crops are depicted in the Figure 4. Study shows that the study area has more potential for plantation crops followed by spices, fruits and vegetables respectively. However, growing a single plantation crop alone would not fully utilize the resources. Hence, high density multispecies cropping system is recommended as per Central Plantation Crops Research Institute (CPCRI), Assam. Limited availability of cultivable land in study area makes it necessary for growing of different annual intercrops and perennial mixed crops in the interspaces of plantations in order to generate additional income per unit area.

At the initial stages of plantation, vegetables such as cabbage, cauliflower, tomato, radish, brinjal etc. can be profitably grown in the interspaces of the seedlings. But gradually only shade loving crops could be grown as component crops. Mixed cropping of fruits as well as intercropping of spices such as ginger, turmeric etc. can also be economically practiced for better utilization of land resources.

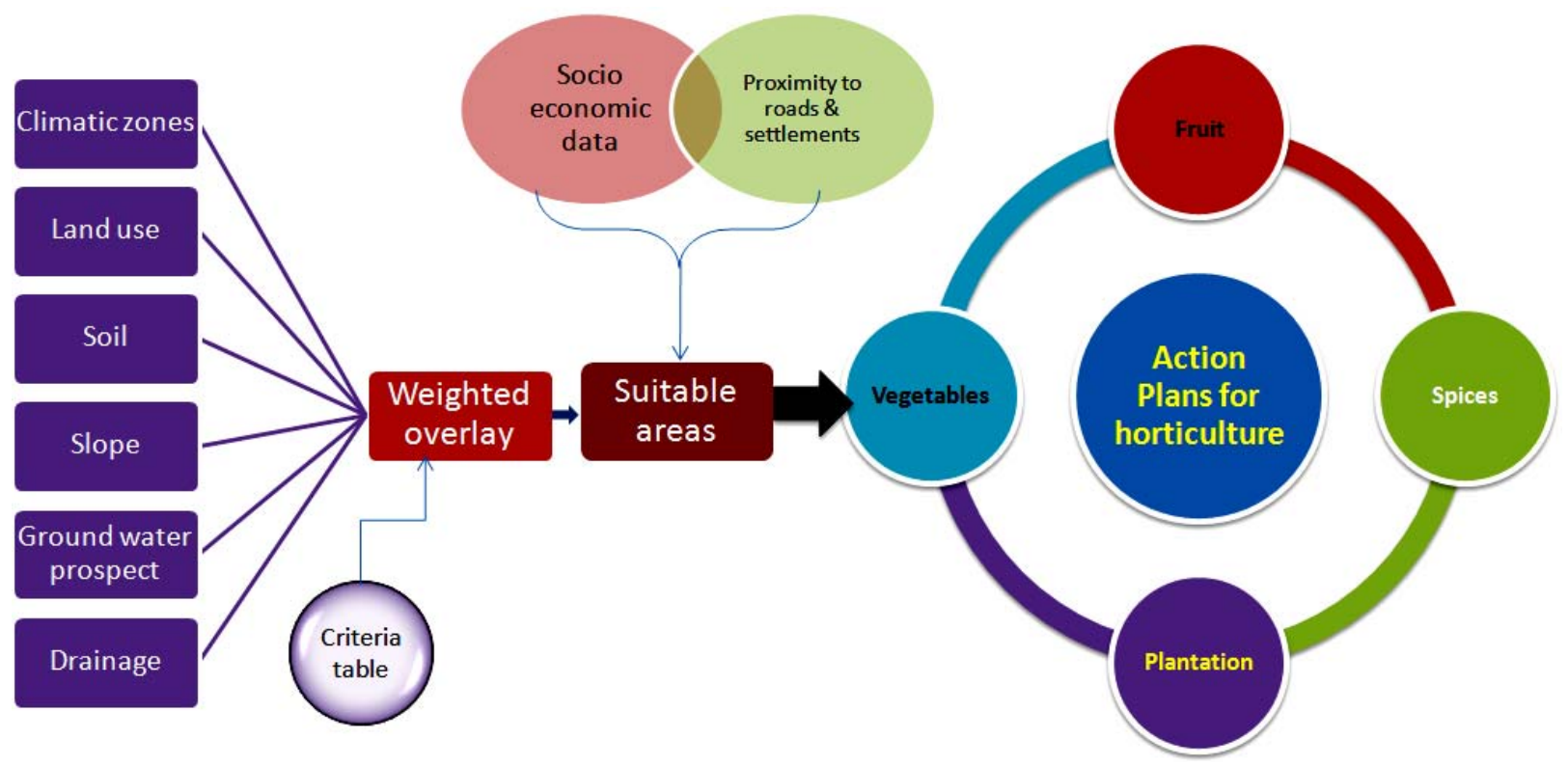

Figure 3. Flowchart-generating inputs for horticultural activities. 
Climatic zone wise detailed statistics on total recommended area under horticulture and percent of area under specific crops or combination of horticultural crops are given in Table 2. Study recommends approximately 1498 $\mathrm{Sq} \cdot \mathrm{km}$ areas for various horticultural activities. Climatic zone CW followed by CEW has highest potential area for expansion of various horticultural crops. About 35\% \& $21 \%$ of total recommended areas of CM \& CW zones respectively are suitable for all four types of suggested crops such as spices, fruits, vegetables as well as plantation. It is also observed that MEW zone has highest potential for plantation crops.
The study also attempts to identify culturable wastelands which can be directly recommended for horticultural development by adopting suitable horticultural crop. Culturable wastelands of $202 \mathrm{Sq} \cdot \mathrm{km}$ areas are available in comparatively high altitudinal colder region of East Khasi Hills district covering only three agroclimatic zones namely CEW, CW and CM (Table 3) out of which $90 \mathrm{Sq} \cdot \mathrm{km}$. areas can be utilized for expansion of horticulture activities. This climatic advantage is reflected in good prices fetched by fruits and vegetables when they are in off-season in neighbouring states.

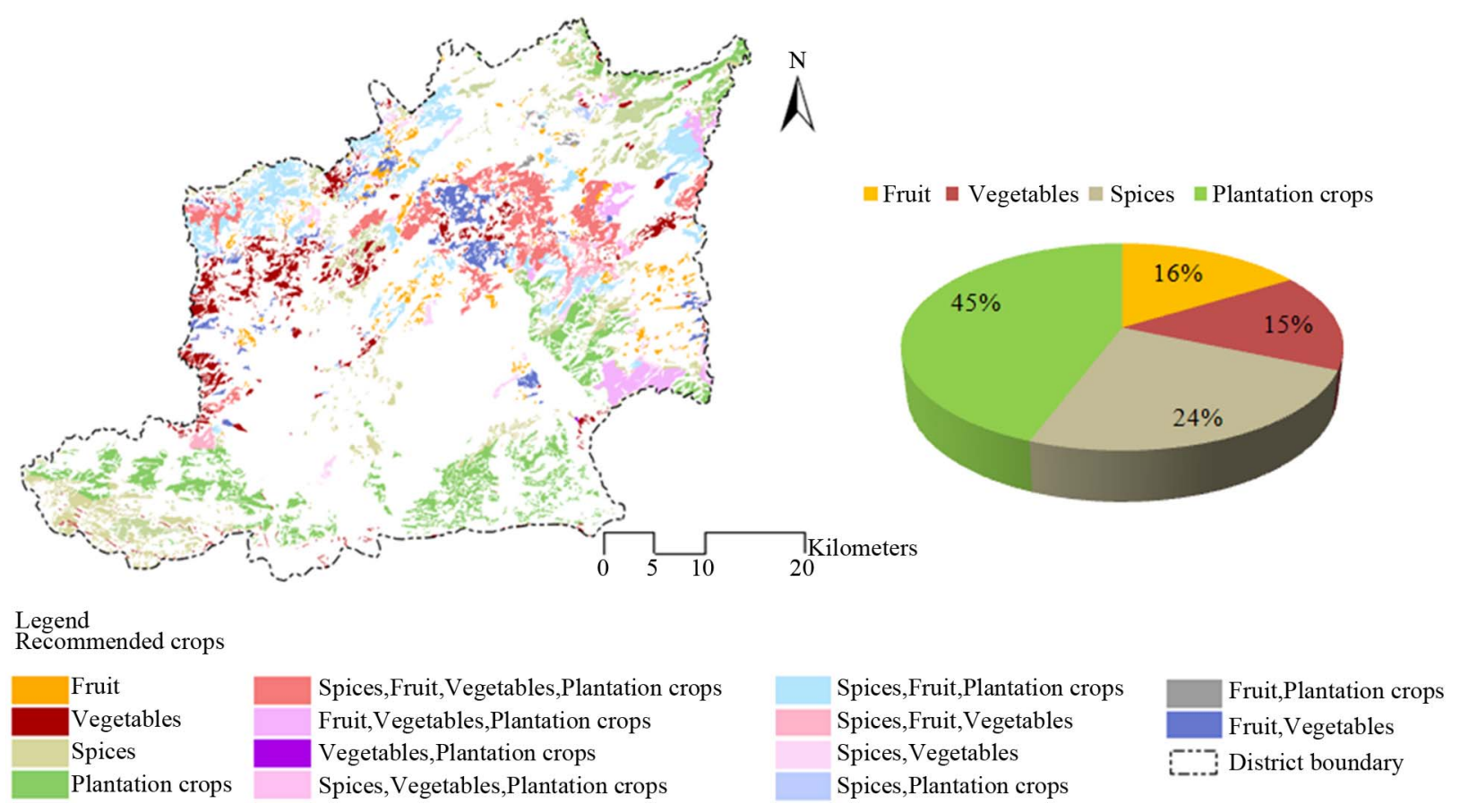

Figure 4. Action plan for horticulture.

Table 2. Climatic zone wise recommended horticulture activities.

\begin{tabular}{|c|c|c|c|c|c|c|c|c|c|c|c|c|c|c|c|}
\hline \multirow{2}{*}{ CZs } & \multirow{2}{*}{$\begin{array}{c}\text { Potential areas } \\
\text { under horticulture } \\
(\mathrm{Sq} \cdot \mathbf{k m})\end{array}$} & \multicolumn{14}{|c|}{ Recommended horticulture crops (\%) } \\
\hline & & $\mathrm{F}$ & $\mathrm{FV}$ & FP & FVP & $\mathrm{P}$ & $\mathrm{S}$ & SF & SFP & SFV & SFVP & SP & SV & SVP & $\mathrm{V}$ \\
\hline CEW & 277.88 & 6 & 8 & 0 & 8 & 12 & 11 & 5 & 16 & 2 & 12 & 2 & 1 & 0 & 17 \\
\hline $\mathrm{CM}$ & 108.12 & 4 & 0 & 3 & 6 & 3 & 7 & 1 & 13 & 0 & 35 & 23 & 2 & 1 & 2 \\
\hline $\mathrm{CW}$ & 416.64 & 6 & 8 & 0 & 9 & 8 & 6 & 3 & 21 & 2 & 21 & 7 & 0 & 1 & 8 \\
\hline HEW & 95.21 & 0 & 1 & 0 & 0 & 64 & 13 & 4 & 0 & 4 & 0 & 2 & 0 & 0 & 5 \\
\hline $\mathrm{HM}$ & 8.18 & 0 & 0 & 0 & 0 & 0 & 0 & 0 & 10 & 0 & 90 & 0 & 0 & 0 & 0 \\
\hline HW & 133.22 & 0 & 0 & 0 & 16 & 36 & 29 & 2 & 3 & 0 & 6 & 6 & 0 & 0 & 2 \\
\hline MEW & 168.11 & 0 & 2 & 0 & 14 & 71 & 5 & 4 & 0 & 3 & 0 & 1 & 0 & 0 & 7 \\
\hline $\mathrm{MM}$ & 50.78 & 0 & 0 & 0 & 14 & 41 & 11 & 1 & 0 & 0 & 14 & 18 & 0 & 0 & 1 \\
\hline MW & 240.25 & 0 & 0 & 0 & 13 & 41 & 13 & 3 & 13 & 0 & 8 & 8 & 0 & 0 & 1 \\
\hline Total & 1498.40 & & & & & & & & & & & & & & \\
\hline
\end{tabular}


Table 3. Recommended horticulture activities in culturable wastelands.

\begin{tabular}{ccc}
\hline CZs & $\begin{array}{c}\text { Culturable wastelands } \\
(\mathrm{Sq} \cdot \mathrm{km})\end{array}$ & $\begin{array}{c}\text { Recommended } \\
\text { horticulture }(\mathrm{Sq} \cdot \mathrm{km})\end{array}$ \\
\hline $\mathrm{CEW}$ & 67.83 & 27.86 \\
$\mathrm{CM}$ & 29.66 & 14.51 \\
$\mathrm{CW}$ & 105.23 & 48.46 \\
Total & 202.72 & 90.83 \\
\hline
\end{tabular}

\section{Conclusion}

An effort has been made to find suitable area for horticulture crop cultivation by analyzing climatic data along with land conditions and land qualities using geospatial technology. It also helps in assessing the feasibility of introducing new crops in new areas. The potential net sown area could be increased if and when the culturable wastelands are utilized for cultivation purposes. Government is taking steps to accelerate the growth of the vegetable sector by encouraging farmers to grow vegetables. On the whole, the revenue returned from horticulture and plantation crops tend to be higher than cereals and encourage permanent cultivation thus having positive impact on the areas which hitherto had been under traditional jhum practices besides supporting food security. Further thrust to be given in popularization and commercialization of low volume high value items like dehydrated mushrooms, indigenous fruits, herbs, spices and plantation crops by bringing more areas under cultivation. The study also confirmed that geospatial technology can be effectively used for demand based location specific planning and management of horticulture/agriculture sectors.

\section{REFERENCES}

[1] A. K. Neog, "WTO and Agriculture Development in Backward Regions,” In: B. J. Deb and B. Dutta Ray, Eds.,
Changing Agriculture Scenario in North East India, Concept Publishing Company, New Delhi, 2006, pp. 25-42.

[2] A. Das, P. K. Ghosh, B. U. Choudhury, D. P. Patel, G. C. Munda, S. V. Ngachan and P. Chowdhury, "Climate change in Northeast India: Recent Facts and EventsWorry for Agricultural Management,” ISPRS Proceedings: Impact of Climate Change on Agriculture, XXXVIII -8/W3, 2009, pp. 31-37.

[3] P. R. Shukla, S. K. Sharma, N. H. Ravindranath, A. Garg and S. Bhattachary (Eds.), "Climate Change and India: Vulnerability Assessment and Adaptation,” Universities Press, Hyderabad, 2003, pp. 1-60.

[4] P. G. Diwakar and S. G. Mayya, "ICT and Geomatics Process Tools for Community Centre Watershed Development,” Journal of Geomatics, Vol. 4, No. 1, 2010, pp. 25-30.

[5] J. Goswami, "Geomatics Based Agroclimatic Characterization of Meghalaya,” Journal of Agrometeorology, Vol. 10, 2008, pp. 164-168.

[6] V. B. Singh, "Climate, Site and Soil,” In: Fruits of NE Region, Wiley Eastern Limited, Bombay, 1990, pp. 1724.

[7] Central Potato Research Station, ICAR, "Package of Practices for Potato Cultivation in Meghalaya,” Shillong, Meghalaya, p. 1.

[8] NBSS\&LUP (ICAR), "Manual Soil Site Suitability Criteria for Major Crops,” Technical Bulletin, Vol. 129, Nagpur, 2006, pp. 3-4, 47-97.

[9] Food and Agriculture Organization (FAO), "A Framework for Land Evaluation,” Soil Bulletin, Vol. 32, United Nations, Rome, 1976. http://www.fao.org/docrep/X5310E/X5310E00.htm

[10] Food and Agriculture Organization (FAO), “Crop Evapotranspiration-Guidelines for Computing Crop Water Requirements,” Irrigation and Drainage Paper 56, 1998. http://www.fao.org/docrep/X0490E/X0490E00.htm

[11] C. Sys, E. van Ranst and J. Debaveye, "Land Evaluation, Part II,” ITC, Ghent, 1991, p. 247. 